\title{
Neuro- embryology
}

\section{No. 1}

Mini-Reviews

1 Critical Periods of Eye Development in Vertebrates with Special Reference to Humans. Second Symposium on Normal and Abnormal Development of the Human Fetal Brain

Wu, Y. (Hong Kong); Lorke, D.E. (Hamburg); Lai, H.; Wai, S.M.; Kung, L.S.; Chan, W.Y.; Yew, D.T.W. (Hong Kong)

9 Tracking Down the Migration of Mouse Neural Crest Cells. Second Symposium on Normal and Abnormal Development of the Human Fetal Brain

Chan, W.Y.; Tam, W.Y.; Yung, K.M.; Cheung, C.S.; Sham, M.H.

(Hong Kong); Copp, A.J. (London)

18 Microglia in the Human Nervous System during Development Second Symposium on Normal and Abnormal Development of the Human Fetal Brain Rezaie, P. (London)

32 Morphogenesis of Type II Lissencephaly: Neuropathology, Genetics and Pathomechanisms. Second Symposium on Normal and Abnormal Development of the Human Fetal Brain Stoltenburg-Didinger, G. (Berlin); Steinbrecher, A. (Berlin/Essen)

Preliminary Note

40 Expression of NMDAR1 in the Human Fetal Amygdala and the Adjacent Ganglionic Eminence

Ulfig, N. (Rostock); Bohl, J. (Mainz); Setzer, M. (Rostock/Frankfurt)

\section{No. 2}

Original Papers

43 The Immunohistochemical Profile of the Normal Conus medullaris and Filum terminale Cummings, T.J.; George, T.M. (Durham, N.C.)

50 Distribution and Morphology of GFAP-Positive Astrocytes in the Human Fetal Brain at Second Trimester

Rezaie, P. (London); Ulfig, N. (Rostock); Male, D. (Milton Keynes)

64 A CD15-Immunoreactive Subpopulation of Radial Glial Cells in the Developing Human Lateral Ganglionic Eminence Mai, J.K. (Düsseldorf); Krajewski, S. (La Jolla, Calif.); Ashwell, K.W.S. (Sydney); Andressen, C. (Düsseldorf)
Review

72 Developmental Aspects of Panic and Related Anxiety Disorders

Hobbs, J.A.; Shekhar, A. (Indianapolis, Ind.)

Mini-Review

81 The Functional Organization of the Developing Human Brain in Relation to Motor Deficits, Cognitive Impairment and Psychotic States. Second Symposium on Normal and Abnormal Development of the Human Fetal Brain Ulfig, N. (Rostock)

94 Symposium Announcement

No. 3

Original Papers

95 Dichlorodiphenyltrichloroethane Specifically Depletes Dopaminergic Neurons in Primary Cell Culture Leung, K.W.; Chan, Y.S.; Yung, K.K.L. (Hong Kong)

103 Postnatal Development of GABAergic Synapses in the Nigral and Entopeduncular Afferent Territory of the Rat Thalamus Kultas-Ilinsky, K. (Iowa City, Iowa); Verney, C. (Paris)

114 Expression of the G-Protein-Coupled Receptor Endothelial Differentiation Gene-2 in the Developing Human Forebrain with Reference to Myelination

Briese, M.; Ulfig, N. (Rostock)

123 Progenitor Cells from Human Embryonic Retina - Proliferation and Preferential Differentiation into Ganglion Cells Andressen, C.; Briese, V.; Ulfig, N. (Rostock)

Preliminary Note

130 Microglia in Fetal and Adult Human Brain Can Be Distinguished from Other Mononuclear Phagocytes through Their Lack of CD163 Expression

Rezaie, P.; Male, D. (Milton Keynes)

Commentary

134 Timing the Insult: Brainstem Necrosis. Further Observations on a Preterm Twin

Stoltenburg-Didinger, G. (Berlin)

138 Book Review
KARGER

\section{(c) 2003 S. Karger AG, Basel}

Fax +41613061234 E-Mail karger@karger.ch www.karger.com
Access to full text and tables of contents, including tentative ones for forthcoming issues: www.karger.com/neb_issues 
No. 4

Original Papers

139 Temporal and Spatial Expressions of Stanniocalcin mRNA in Mouse Brains

Yeung, H.Y.; Chan, D.K.O.; Wong, C.K.C. (Hong Kong)

143 The Molecular Synaptosomal Deficit in Down Syndrome Starts Early in Life Pollak, D. (Vienna); Fountoulakis, M. (Basel); Lubec, G. (Vienna)

147 Overexpression of Interferon $\alpha / \beta$ Receptor $\beta$ Chain in Fetal Down Syndrome Brain

Ferrando-Miguel, R.; Shim, K.-S.; Cheon, M.S. (Vienna); Gimona, M. (Salzburg); Furuse, M. (Kyoto); Lubec, G. (Vienna)

156 Abnormalities of Interstitial Cells of Cajal in Dominant Megacolon Mice

Tam, W.Y.; Yip, F.P.; Chan, W.Y. (Hong Kong)

164 Migration of Hindbrain Neural Crest Cells in the Mouse Cheung, C.S.; Wang, L.; Dong, M.; Chan, W.Y. (Hong Kong)
Mini-Review

175 Genetic, Environmental and Immunologic Factors in the Etiology of Autism Spectrum Disorders Bölte, S.; Poustka, F. (Frankfurt/M.)

Abstracts

180 Third International Symposium on Normal and Abnormal Development of the Human Fetal Brain. Croatian Institute for Brain Research, School of Medicine, University of Zagreb, Croatia, June 13-15, 2003

189 Author Index Vol. 4, 2003

190 Subject Index Vol. 4, 2003 